\title{
Implementation of the Simple Multi Attribute Rating Technique Method (SMART) in Determining Toddler Growth
}

\author{
Agung Wahana ${ }^{1}$, Cecep Nurul Alam ${ }^{2}$, Siti Nur Rohmah ${ }^{3}$ \\ 1,2,3 Department of Informatics, UIN Sunan Gunung Djati Bandung, Indonesia
}

\begin{tabular}{l} 
Article Info \\
\hline Article history: \\
Received September 09, 2020 \\
Revised November 22, 2020 \\
Accepted November 26, 2020 \\
Published December 30, 2020
\end{tabular}

\section{Keywords:}

Decision Support System

SMART

Toddler's growth and development

\begin{abstract}
Toddler nutritional status is an important factor in efforts to reduce child mortality. The development of community nutrition can be monitored through the results of recording and reporting of community nutrition improvement programs reflected in the results of weighing infants and toddlers every month at the Pos Pelayanan Terpadu (Posyandu/ Integrated Service Post), where these efforts aim to maintain and improve health and prevent and cope with the emergence of public health problems, especially aimed at toddlers. However, in carrying out the health service activities of Medical Officers, faced with an important problem that is still difficult in providing information related to the results of monitoring the growth and development of infants, because information on growth and development of infants owned is obtained from the data collection done manually such as; make records and calculations to find out the condition of a toddler declared good, less, or bad. Implementation of the SMART method in Toddler's growth and development, this method can be used based on the weights and criteria that have been determined. The criteria used are based on the Anthropometric index assessment criteria. The results of the analysis are the results of ranking the greatest value to be used as the material in the decisionmaking process.
\end{abstract}

\section{Corresponding Author:}

Agung Wahana, Department of Informatics, UIN Sunan Gunung Djati Bandung, Jl. AH. Nasution No. 105 Badung, Indonesia Email: wahana.agung@uinsgd.ac.id

\section{INTRODUCTION}

Attention and treatment for toddler health at this time needs to be improved, making it a priority for parents and the health care team, to avoid the risks that might occur. The use of a Card to Healthy (Kartu Menuju Sehat/KMS) that just goes away makes parents and midwives unable to properly monitor the growth and development of toddlers [1][2][3]. Not to mention in writing data in KMS there are often errors due to inaccurate calculations. Technological advances that are developing rapidly in this era of globalization, have spread to human life in various fields. One example is the use of computers as one of the tools used for process information that can produce better and more useful output. Even in the health sector, it cannot be denied that current information technology has made it a daily necessity. With the discovery of a tool that can be used as an aid for medical professionals doing health activities such as the field of medicine, hospital organization, as well as the development of health science research.

Problems that occur in children, namely nutrition [4] problems are problems that are still seeking a solution by what was stated by the Ministry of Health (Kemenkes) RI. Some factors that cause many cases of malnutrition [5] occur in toddlers both clinical and non-clinical factors, such as not optimal health services, not complying with clinical protocol standards, or incomplete medical records. In addition to the examples listed above, the lack of health monitoring or growth and development of infants is caused by the records contained 
on the Card to Health in their use is not optimal. The data processed results in information about the health of children under five years old which is used as a reference for growth and development to be inaccurate because it is not optimal performance. So that makes the relevant agencies experience delays in handling cases that might occur.

Related institutions here are one of the health services for toddlers. Pos Pelayanan Terpadu (Posyandu / Integrated Service Post) is the center of community activities in efforts to provide health services and family planning, where the community can get services provided by the government, one of the examples relating to toddlers' health, such as immunization, nutrition, and prevention of diarrhea [6].

The toddler's data report that is stored in this Posyandu is in the form of a Posyandu notebook. In this book, there is data on children under five along with the results of weighing which is done once a month. To see the growth of toddlers every month, it is still going through the process of recording in a notebook, starting from recording the measurement results than looking at the WHO reference table in 2005 to determine the nutritional status of toddlers.

The selection of the SMART [7][8][9][10][11] method used provides convenience in making decisions and ease in analyzing data that can be taken by decision-makers. This method is also said to be quite effective and flexible. Said to be a multi-criteria decision-making method, which each criterion has the values and weights that are used as a reference for the best alternative assessment.

Humans in carrying out daily activities can not be separated from food as an energy fulfillment. Certainly, digested food must contain good nutrition. Understanding nutrition itself is a substance contained in food, can be directly utilized by the body. These substances are in the form of vitamins, carbohydrates, protein, fat, water, and minerals. In infancy, balanced nutrition is needed to improve the growth period which can be said as the golden age. Parents should be more able to pay attention to the needs of toddlers regarding the nutrition needed by the child in their growth and development. Of course, the selection of good food will affect the growth of the child. Growth is a process of physical change, which is quantitative, whereas development itself is a refinement of a qualitative growth process. This research is expected to provide information about the growth and development of toddlers who are recorded every month, especially for under-nutrition children so that efforts can be made to improve the nutrition of toddlers.

\section{METHOD}

\subsection{Method of Simple Multi-Attribute Rating Technique (SMART)}

Categorized as a multi-criteria decision-making method. Each criterion is given a value and weight or has a value and weight to be used as a benchmark in determining an alternative that is best assessed on a particular problem [7][12].

To do the weighting of each attribute, the following steps are taken:

a. Make levels from worst to best for each attribute's importance

b. Giving the importance of each attribute by comparing the ratios below it

c. The SMART method uses the equation model (1) as follows:

$$
u i(a i)=\sum_{j=1}^{m} w j u i(a i), 1=1,2, \ldots m
$$

Note:

$w j=$ weighting values for the $\mathrm{j}$ criteria and the $\mathrm{i}$ criteria

ui (ai) $=$ alternative utility value for the $\mathrm{i}$ criterion

The steps of the SMART method[13]

a. Determine the number of criteria

b. Provide input priority values on systems with a scale of $0-100$, then weights are normalized using equation (2)

Note:

$$
N j=\frac{w j}{\sum W j}
$$

$\mathrm{Nj}=$ Normalization of weights

$\mathrm{Wj}=$ the weight of a criterion 
$\sum w j=$ total weighting of all criteria

c. Each alternative is given a criterion value

d. Calculate the utility value for each criterion by using equation (3)

$$
u i(a i)=\frac{(\text { Couti-Cmin })}{(\text { Cmax }- \text { Cmin })} \times 100 \%
$$

Note:

ui (ai) = alternative utility value 1 for the $\mathrm{i}$ criteria

$\mathrm{Cmax}=$ maximum criterion value

$\mathrm{Cmin}=$ minimum criterion value

Couti $=$ i criterion value

e. Calculate the final value for each of the alternatives:

$$
u i(a i)=\sum_{j=1}^{m} n j u i(a i)
$$

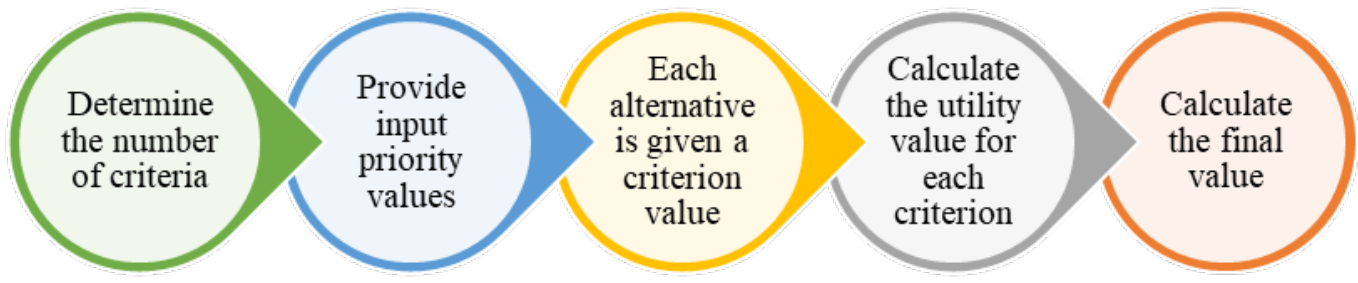

Figure 1. The steps of the SMART method

\subsection{Software Development Method}

The method used in software development is a prototype. The prototype[14][15] itself is a method that acts as the performance stages of a system before the actual activity stage is carried out.

The stages of the prototype method are:

a. Listen to customers. It is a process of designing a needs system by listening to complaints and requests directly from the customer.

b. Build/Revise Mock-Up. This is a stage where the prototype system bolted and designed. User or customer complaints serve as a reference for the need to make a prototype.

c. Customer test drives Mock-up. Prototypes that have been designed from the system are tested try by customers or users. Shortcomings are the evaluation of the design is needed. Development later.

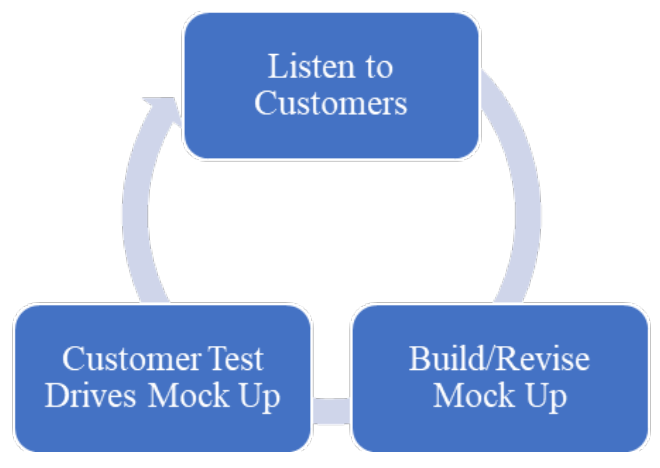

Figure 2. The Stage of the prototype method

\section{RESULTS AND DISCUSSION}

\subsection{Calculation Method of Simple Multi-Attribute Rating Technique (SMART)}

SMART is categorized as a multi-criteria decision-making method. Each criterion is given a value and weight or has a value and weight to be used as a benchmark in determining an alternative is best assessed on a particular problem. Following are the steps of the SMART method itself: 


\subsubsection{Required Criteria}

a. Weight by Age (W/A)

Table 1. Criteria for $\mathrm{W} / \mathrm{A}$

\begin{tabular}{lcc}
\hline & W/A & Value \\
\hline Malnutrition & 100 \\
Poor Nutrition & 80 \\
Good Nutrition & 60 \\
More Nutrition & 50 \\
\hline
\end{tabular}

b. Height by Age (H / A)

Table 2. H / A Criteria

\begin{tabular}{|c|c|}
\hline $\mathbf{H} / \mathbf{A}$ & Value \\
\hline Very Short & 100 \\
\hline Short & 80 \\
\hline Normal & 50 \\
\hline High & 10 \\
\hline
\end{tabular}

c. Weight by Height $(\mathrm{W} / \mathrm{H})$

Table 3. W / H Criteria

\begin{tabular}{lcc}
\hline & W / H & Value \\
\hline Very Skinny & 100 & \\
Skinny & 80 & \\
Normal & 50 & \\
Fat & 10 & \\
\hline
\end{tabular}

\subsubsection{Stage of Presentation of Criteria Weights}

Below is a weight presentation used to determine nutritional status bad in toddlers:

Table 4. Criteria Weight

\begin{tabular}{ccc}
\hline Criteria Name & Weight $\mathbf{W j}$ & Description \\
\hline $\mathrm{W} / \mathrm{A}$ & $35 \%$ & $\mathrm{C} 1$ \\
$\mathrm{D} / \mathrm{A}$ & $35 \%$ & $\mathrm{C} 2$ \\
$\mathrm{~W} / \mathrm{H}$ & $30 \%$ & $\mathrm{C} 3$ \\
\hline
\end{tabular}

\subsubsection{Weights normalization stage}

Table 5. Weights Normalization Stage

\begin{tabular}{ccc}
\hline Name Criteria & Weight $(\mathbf{W j})$ & Normalization $\mathbf{( N j )}$ \\
\hline $\mathrm{W} / \mathrm{A}$ & $35 \%$ & $35 / 100=0.35$ \\
$\mathrm{H} / \mathrm{A}$ & $35 \%$ & $35 / 100=0.35$ \\
$\mathrm{~W} / \mathrm{H}$ & $30 \%$ & $30 / 100=0.3$ \\
\hline
\end{tabular}

The data used in the SMART calculation example uses 5 toddlers data then 2 toddlers are chosen with the highest score as a toddler with poor nutrition. Make a decision matrix by determining the criterion value of each alternative.

Table 6. The Alternative Decision Matrix for Each criterion

\begin{tabular}{cccc}
\hline Data & C1 & C2 & C3 \\
\hline A1 & 80 & 50 & 80 \\
A2 & 60 & 50 & 50 \\
A3 & 60 & 50 & 50 \\
A4 & 60 & 50 & 50 \\
A5 & 80 & 80 & 50 \\
A6 & 80 & 80 & 50 \\
\hline
\end{tabular}

\subsubsection{The calculation phase of the utility value of each criterion}

a. Utility criterion 1 for alternative i (u1 (ai))

$$
\begin{aligned}
& u 1(a 1)=\frac{80-50}{100-50}=\frac{30}{50}=0,6 \\
& u 1(a 2)=\frac{60-50}{100-50}=\frac{10}{50}=0,2 \\
& u 1(a 3)=\frac{60-50}{100-50}=\frac{10}{50}=0,2 \\
& u 1(a 4)=\frac{60-50}{100-50}=\frac{10}{50}=0,2
\end{aligned}
$$




$$
\begin{aligned}
& u 1(a 5)=\frac{60-50}{100-50}=\frac{60}{50}=0,2 \\
& u 1(a 6)=\frac{80-50}{100-50}=\frac{30}{50}=0,6
\end{aligned}
$$

b. Utility criterion 2 for alternative i (u1 (ai))

$$
\begin{aligned}
& u 2(a 1)=\frac{50-10}{100-10}=\frac{40}{90}=0,44 \\
& u 2(a 2)=\frac{50-10}{100-10}=\frac{40}{90}=0,44 \\
& u 2(a 3)=\frac{50-10}{100-10}=\frac{40}{90}=0,44 \\
& u 2(a 4)=\frac{50-10}{100-10}=\frac{40}{90}=0,44 \\
& u 2(a 5)=\frac{80-10}{100-10}=\frac{70}{90}=0,78 \\
& u 2(a 6)=\frac{80-10}{100-10}=\frac{70}{90}=0,78
\end{aligned}
$$

c. Utility criterion 3 for alternative i (u1 (ai))

$$
\begin{aligned}
& u 3(a 1)=\frac{80-10}{100-10}=\frac{70}{90}=0,78 \\
& u 3(a 2)=\frac{50-10}{100-10}=\frac{40}{90}=0,44 \\
& u 3(a 3)=\frac{50-10}{100-10}=\frac{40}{90}=0,44 \\
& u 3(a 4)=\frac{50-10}{100-10}=\frac{40}{90}=0,44 \\
& u 3(a 5)=\frac{50-10}{100-10}=\frac{70}{90}=0,78 \\
& u 3(a 6)=\frac{50-10}{100-10}=\frac{70}{90}=0,78
\end{aligned}
$$

\subsubsection{The final calculation phase}
$\mathrm{A} 1=(0,6 \times 0,35)+(0,44 \times 0,35)+(0,78 \times 0,3)$
$=0,598$ Malnutrition
$\mathrm{A} 2=(0,2 \times 0,35)+(0,44 \times 0,35)+(0,44 \times 0,3)$

\begin{tabular}{|c|c|c|c|c|c|}
\hline No & Data & Criteria & $\begin{array}{c}\text { SMART Manual } \\
\text { Preference Value (SM) }\end{array}$ & $\begin{array}{c}\text { SMART System } \\
\text { Preference Value (SS) }\end{array}$ & Matching \\
\hline \multirow[t]{3}{*}{1} & A1 & $\mathrm{C} 1$ & 0,210 & 0,198 & $x$ \\
\hline & & $\mathrm{C} 2$ & 0,156 & 0,145 & \\
\hline & & C3 & 0,233 & 0,220 & \\
\hline \multirow[t]{3}{*}{2} & $\mathrm{~A} 2$ & $\mathrm{C} 1$ & 0,070 & 0,070 & $\checkmark$ \\
\hline & & $\mathrm{C} 2$ & 0,156 & 0,156 & \\
\hline & & $\mathrm{C} 3$ & 0,133 & 0,133 & \\
\hline \multirow[t]{3}{*}{3} & $\mathrm{~A} 3$ & $\mathrm{C} 1$ & 0,070 & 0,070 & $\checkmark$ \\
\hline & & $\mathrm{C} 2$ & 0,156 & 0,156 & \\
\hline & & $\mathrm{C} 3$ & 0,133 & 0,133 & \\
\hline \multirow[t]{3}{*}{4} & A4 & $\mathrm{C} 1$ & 0,070 & 0,070 & $\checkmark$ \\
\hline & & $\mathrm{C} 2$ & 0,156 & 0,156 & \\
\hline & & C3 & 0,133 & 0,133 & \\
\hline \multirow[t]{3}{*}{5} & A5 & $\mathrm{C} 1$ & 0,070 & 0,070 & $\checkmark$ \\
\hline & & $\mathrm{C} 2$ & 0,156 & 0,156 & \\
\hline & & C3 & 0,133 & 0,133 & \\
\hline \multirow[t]{2}{*}{6} & A6 & $\mathrm{C} 1$ & 0,070 & 0,070 & $\checkmark$ \\
\hline & & $\mathrm{C} 2$ & 0,156 & 0,156 & \\
\hline
\end{tabular}
$=0,356$ Good Nutrition
$\mathrm{A} 3=(1 \times 0,35)+(0,67 \times 0,35)+(0,67 \times 0,3)$
$=0,356$ Good Nutrition
$\mathrm{A} 4=(0,2 \times 0,35)+(0,44 \times 0,35)+(0,44 \times 0,3)$
$=0,356$ Good Nutrition
$\mathrm{A} 5=(0,2 \times 0,35)+(0,78 \times 0,35)+(0,44 \times 0,3)$
$=0,475$ Malnutrition
$\mathrm{A} 6=(0,6 \times 0,35)+(0,78 \times 0,35)+(0,44 \times 0,3)$
$=0,615$ Malnutrition

Values that are in the range of 0.60 to 0.75 are A5 and A6. So that alternatives A5 and A6 are thought to have experienced malnutrition.

Based on the data tested as many as 15 toddlers data obtained results like the following table 7 :

Table 7. SMART and Manual Testing Results 


\begin{tabular}{|c|c|c|c|c|c|}
\hline No & Data & Criteria & $\begin{array}{c}\text { SMART Manual } \\
\text { Preference Value (SM) }\end{array}$ & $\begin{array}{c}\text { SMART System } \\
\text { Preference Value (SS) }\end{array}$ & Matching \\
\hline \multirow{4}{*}{7} & & $\mathrm{C} 3$ & 0,133 & 0,133 & \\
\hline & A7 & $\mathrm{C} 1$ & 0,070 & 0,070 & $\checkmark$ \\
\hline & & $\mathrm{C} 2$ & 0,156 & 0,156 & \\
\hline & & $\mathrm{C} 3$ & 0,133 & 0,133 & \\
\hline \multirow[t]{3}{*}{8} & A 8 & $\mathrm{C} 1$ & 0,070 & 0,070 & $\checkmark$ \\
\hline & & $\mathrm{C} 2$ & 0,156 & 0,156 & \\
\hline & & $\mathrm{C} 3$ & 0,133 & 0,133 & \\
\hline \multirow[t]{3}{*}{9} & A9 & $\mathrm{C} 1$ & 0,350 & 0,350 & $x$ \\
\hline & & $\mathrm{C} 2$ & 0,272 & 0,275 & \\
\hline & & $\mathrm{C} 3$ & 0,133 & 0,135 & \\
\hline \multirow[t]{3}{*}{10} & $\mathrm{~A} 10$ & $\mathrm{C} 1$ & 0,070 & 0,070 & $\checkmark$ \\
\hline & & $\mathrm{C} 2$ & 0,156 & 0,156 & \\
\hline & & $\mathrm{C} 3$ & 0,133 & 0,133 & \\
\hline \multirow[t]{3}{*}{11} & A11 & $\mathrm{K} 1$ & 0,070 & 0,070 & $\checkmark$ \\
\hline & & $\mathrm{K} 2$ & 0,156 & 0,156 & \\
\hline & & $\mathrm{K} 3$ & 0,133 & 0,133 & \\
\hline \multirow[t]{3}{*}{12} & $\mathrm{~A} 12$ & $\mathrm{~K} 1$ & 0,070 & 0,070 & $\checkmark$ \\
\hline & & $\mathrm{K} 2$ & 0,156 & 0,156 & \\
\hline & & $\mathrm{K} 3$ & 0,133 & 0,133 & \\
\hline \multirow[t]{3}{*}{13} & A13 & $\mathrm{K} 1$ & 0,070 & 0,070 & $\checkmark$ \\
\hline & & $\mathrm{K} 2$ & 0,272 & 0,272 & \\
\hline & & $\mathrm{K} 3$ & 0,133 & 0,133 & \\
\hline \multirow[t]{3}{*}{14} & A14 & $\mathrm{K} 1$ & 0,210 & 0,210 & $\checkmark$ \\
\hline & & $\mathrm{K} 2$ & 0,272 & 0,272 & \\
\hline & & $\mathrm{K} 3$ & 0,133 & 0,133 & \\
\hline \multirow[t]{3}{*}{15} & A 15 & $\mathrm{~K} 1$ & 0,070 & 0,070 & $\checkmark$ \\
\hline & & $\mathrm{K} 2$ & 0,272 & 0,272 & \\
\hline & & $\mathrm{K} 3$ & 0,133 & 0,133 & \\
\hline
\end{tabular}

The testing data used which amounted to 15 data are shown in Table 6, while the total amount of data is 107 data, Table 6 displays the final value of each alternative assessment (toddler) by comparing the results of manual calculations and also the calculation of the SMART method, wherein Table 6 explains the results of a match between the testing data and the data from the manual calculation results are the same.

The accuracy level of the implementation of the SMART method uses equations:

$$
\begin{aligned}
& \text { Level of Accuracy }=\frac{\text { Correct Number of Matches }}{\text { Correct Number of Matches+ Incorrect Number of Matches }} \times 100 \% \\
& \text { Level of Accuracy }=\frac{95}{95+12} \times 100 \% \\
& \text { Level of Accuracy }=93 \%
\end{aligned}
$$

\section{CONCLUSION}

The implementation of the SMART method in determining the growth and development of toddlers with weight criteria according to age, height according to age, and weight according to height gives good results through the process of calculating the utility value and the final value calculation process. The results of tests that have been carried out using data as many as 107 toddlers the same result of $93 \%$ between the calculation with the SMART method and manual calculations show that the SMART method can be used to determine the growth and development of toddlers.

\section{ACKNOWLEDGMENTS}

Authors wishing to acknowledge the Research and Publication Centre of UIN Sunan Gunung Djati Bandung, Faculty of Science and Technology, and Department of Informatics that supports and funds this research publication.

\section{REFERENCES}

[1] R. Butchon and T. Liabsuetrakul, "The Development and Growth of Children Aged under 5 years in Northeastern Thailand: a Cross-Sectional Study,” J. Child Adolesc. Behav., vol. 05, no. 01, pp. 1-6, 2017, doi: 10.4172/23754494.1000334

[2] M. Murdiningsih and N. Komariah, "Knowledge and parenting patterns with toddler's growth and development," Int. J. Public Heal. Sci., vol. 8, no. 2, p. 179, 2019, doi: 10.11591/ijphs.v8i2.17808.

Implementation of the Simple Multi Attribute Rating Technique Method (SMART) in Determining 
[3] E. M. Sibarani, M. Nadial, E. Panggabean, and S. Meryana, "A study of parsing process on natural language processing in bahasa Indonesia," Proc. - 16th IEEE Int. Conf. Comput. Sci. Eng. CSE 2013, pp. 309-316, 2013, doi: 10.1109/CSE.2013.56.

[4] M. De Onis, A. W. Onyango, E. Borghi, C. Garza, and H. Yang, "Comparison of the World Health Organization (WHO) Child Growth Standards and the National Center for Health Statistics/WHO international growth reference: Implications for child health programmes," Public Health Nutr., vol. 9, no. 7, pp. 942-947, 2006, doi: 10.1017/PHN20062005.

[5] M. Blössner, M. De Onis, and W. H. Organization, "Malnutrition: quantifying the health impact at national and local levels," Environ. Burd. Dis. Ser., vol. 12, no. 12, p. 43, 2005, doi: 10.1371/journal.pone.0107040.

[6] O. Soedirham, "Integrated Services Post (Posyandu) as Sociocultural Approach for Primary Health Care Issue," Kesmas Natl. Public Heal. J., vol. 7, no. 5, p. 195, 2012, doi: 10.21109/kesmas.v7i5.40.

[7] D. Siregar, D. Arisandi, A. Usman, D. Irwan, and R. Rahim, "Research of Simple Multi-Attribute Rating Technique for Decision Support," J. Phys. Conf. Ser., vol. 930, no. 1, 2017, doi: 10.1088/17426596/930/1/012015.

[8] O. Sihombing et al., "Determining Outstanding Employee Using Simple Multi-Attribute Rating Technique Method," J. Phys. Conf. Ser., vol. 1230, no. 1, 2019, doi: 10.1088/1742-6596/1230/1/012076.

[9] C. Slamet, F. M. Maliki, U. Syaripudin, A. S. Amin, and M. A. Ramdhani, "Thesis topic recommendation using simple multi attribute rating technique," J. Phys. Conf. Ser., vol. 1402, no. 6, 2019, doi: 10.1088/17426596/1402/6/066105.

[10] R. Risawandi and R. Rahim, "Study of the Simple Multi-Attribute Rating Technique For Decision Support," Int. J. Sci. Res. Sci. Technol., vol. 2, no. 6, pp. 491-494, 2016.

[11] D. Borissova and D. Keremedchiev, "Group Decision Making in Evaluation and Ranking of Students by Extended Simple Multi-Attribute Rating Technique," Cybern. Inf. Technol., vol. 19, no. 3, pp. 45-56, 2019, doi: 10.2478/cait-2019-0025.

[12] P. Nag, S. Mondal, F. Ahmed, A. More, and M. Raihan, "A simple acute myocardial infarction (Heart Attack) prediction system using clinical data and data mining techniques," 20th Int. Conf. Comput. Inf. Technol. ICCIT 2017, vol. 2018-Janua, pp. 1-6, 2018, doi: 10.1109/ICCITECHN.2017.8281809.

[13] O. Ogbeiwi, "Why written objectives need to be really SMART," Br. J. Heal. Care Manag., vol. 23, no. 7, pp. 324-336, 2017, doi: 10.12968/bjhc.2017.23.7.324.

[14] B. Suranto, "Software prototypes: Enhancing the quality of requirements engineering process," 2nd Int. Symp. Technol. Manag. Emerg. Technol. ISTMET 2015 - Proceeding, pp. 148-153, 2015, doi: 10.1109/ISTMET.2015.7359019.

[15] M. Käpyaho and M. Kauppinen, “Agile requirements engineering with prototyping: A case study," 2015 IEEE 23rd Int. Requir. Eng. Conf. RE 2015 - Proc., pp. 334-343, 2015, doi: 10.1109/RE.2015.7320450. 